\title{
The Discussion about Poverty Alleviation Migration Relocation Problems and Countermeasures from the Perspective of Precise Poverty Alleviation

\author{
Feng-Ke WANG ${ }^{1, a}$, Dan WANG ${ }^{2, b,{ }^{*}}$ \\ ${ }^{1}$ School of Management, Henan University of Science and Technology, Luoyang, Henan \\ afengkewang@126.com, b5928770852qq.com \\ ${ }^{*}$ Corresponding author
} \\ ${ }^{2}$ School of Management, Henan University of Science and Technology, Luoyang, Henan,
}

\begin{abstract}
Keywords: Precise poverty alleviation, Poverty alleviation migration relocation, Problems and countermeasures.
\end{abstract}

\begin{abstract}
This paper based on the background of the new era of China's great poverty alleviation and reviewed the researches on poverty alleviation at home and abroad, selected some relieve poverty relocate immigrants from poverty alleviation during the period of precise poverty alleviation in Luoyang, Henan Province as the research object. This paper summarizes the current situation and existing problems of poverty alleviation and relocation, and puts forward some pertinent suggestions.
\end{abstract}

\section{Research Background}

The problem of poverty has become one of the sharpest social problems in the world today. The political parties, governments and all walks of life have always attached great importance to the problem of poverty. When New China was just established, due to historical and long-term wars and other issues led to economic backwardness, poor condition. To a certain extent, the implementation of the planned economy has made China's poverty problem relieved, but China's rural areas were in a state of general poverty. After Reform and Opening, under the leadership of the new leader, China has solved the problem of food and clothing for hundreds of millions of rural poor people in China. The number of poor people has been reduced by 790 million, the incidence of poverty has dropped from $10.2 \%$ to below $4 \%$.It has contributed over $70 \%$ to the global poverty reduction and has become the country with the largest poverty reduction population in the world. It has explored and accumulated many valuable experiences.

Eliminating poverty is one of the development goals of all countries in the world and an inevitable choice for China to realize its common prosperity and realize the China dream of the great rejuvenation of the Chinese nation. China has made a series of developments and progress in the process of poverty alleviation: First, poverty alleviation has promoted the economic development rapidly and provided the impetus for economic growth. Second, poverty alleviation made the allocation of resources more reasonable and promoted the coordinated development of the region, it is beneficial to the stability of the society. Third, poverty alleviation has accelerated the optimization of the economic structure and employment structure. The second and third industries have been developing faster, and the number of second and third industries has been increasing. Fourth, poverty alleviation helps to solve the problems of agriculture, countryside and farmers. It improves the environment of rural life and production. It has changed the passive situation in which peasants can only rely on agriculture for a long time, and many farmers have gained new life in the process of poverty alleviation.

In October 2017, in the report of the nineteenth Congress of the Communist Party of China, general secretary $\mathrm{Xi}$ Jinping pointed out, China has made decisive progress in its fight against poverty. About 60 million people are steadily out of poverty, and the incidence of poverty has fallen from $10.2 \%$ to less than $4 \%$ [1].Behind the gratifying achievements, we have become more and more clearly aware that there are a series of problems in the process of poverty alleviation in China: 
First, inaccurate object identification(scale exclusion, regional exclusion, recognition exclusion, etc)[2].Second, poverty alleviation funds can not be put in place (funds can not be earmarked; funds can not reach the hands of the poor actually).Third, imperfect supervision mechanism of poverty alleviation (the evaluation of poverty alleviation work and the effect of poverty alleviation are not evaluated).Fourth, the force of poverty alleviation is single (social groups, social organizations, individuals less involved and the lack of access)[3].As early as November 2013, when general secretary Xi Jinping inspects in Xiangxi, Hunan, he put forward the concept of "precision poverty alleviation":"Poverty alleviation should seek truth from facts, according to local conditions. To accurately poverty alleviation and avoid shouting slogans." On December 31, 2017, General Secretary Xi Jinping once again mentioned in the New Year's message of 2018 that more than 10 million rural poor people have been lifted out of poverty and 3.4 million rural poor people have achieved poverty alleviation and relocation in 2017."It is our solemn commitment that poverty will be eradicated in rural areas by 2020 under the current standards in our country. And the whole society should take action, make a battle, implement the strategy accurately, and win the new victory. "Relocating the poor as one of the means of precision poverty alleviation is a complex economic and social project. In reality, there are many problems in poverty alleviation and relocation. As the most active factor and the closest stakeholder in the process of poverty alleviation, the investigation of poverty alleviation and resettlement immigrants can most reflect the effect of precise poverty alleviation directly. Therefore, it is necessary to draw the vision from the government's immigration policy to the living status of immigrants, pay attention to the satisfaction of relocated immigrants after relocation, and promote the healthy development of precision poverty alleviation.

\section{ResearchSignificance}

Winning the Poverty Alleviation and ensuring that the poor in rural areas are out of poverty by the current standards of 2020 are the major measure to promote the entire people to share the fruits of reform and development and realize common prosperity. It is an important way to promote the coordinated development of the region and cross the "middle-income trap". It is an important guarantee to promote unity and border security of the nation,it is an important part of building moderately prosperous society. It is an important action to respond positively to the United Nations agenda for sustainable development in 2030. It is a matter of the people's well-being. It concerns the party's governing foundation and the country's long-term peace and order, its mission is glorious and its responsibilities are significant [4]. This article focuses on the immigration problem caused by adopting the mode of relocation of poverty alleviation in the process of precise poverty alleviation from the perspective of "human development". From the point of view of relocating migrants, we investigate the actual situation of poverty alleviation at present; this survey has an important impact on testing the effectiveness of accurate poverty alleviation, re-understanding and understanding the precise poverty alleviation. In this paper, based on the large-scale empirical research, puts forward some policy suggestions with strong pertinence and realism. It has a wider reference value and practical guiding significance for breaking the mindset of paying too much attention to government policies and the quantity of relocation for a long time.

For precision poverty alleviation, the future will pay more attention to quality rather than speed, placing more emphasis on making development achievements more fruitful and more equitable for people [5]. Relocation Poverty Alleviation Resettlement is not the end of the poverty alleviation work. In the process of poverty alleviation and relocation, the identity of peasants will be transformed into immigrants, and the way of life will be greatly changed. Through in-depth research on the psychological adaptation, cultural symbiosis and group integration, we can find that the problems existing in the process of relocation of precise poverty alleviation immigrants and the targeted solutions which are proposed to help to build a reasonable development model with characteristics that are conducive to precision poverty alleviation and provide a reference for the work of the government social management, so as to promote poverty alleviation work faster and better, and ultimately achieve common prosperity. 


\section{Related Research Progress}

\section{ForeignResearch Progresses}

\section{Poverty}

Poverty is ubiquitous all over the world, and it is the result of many factors such as economy, society, culture and natural environment. The domestic and foreign experts and scholars have studied it from different disciplines such as economics, sociology and management. Malthus, as a pioneer in the study of poverty, proposed the theory of "population trap" in his book "Principles of Population" in 1798. The theory suggests that poverty can only be caused when the population growth rate is less than the growth rate of material production. In 1901, Lens defined "poverty" in his book "Poverty: the study of town life": that is the income of a family can't meet the most basic needs. Due to the western countries research on "poverty" earlier, many mature theoretical views have been formed:

First, "the theory of rights and poverty" was proposed by India's AmartyaSen in the 21st century. In his opinion, the lack of rights is the root cause of poverty. Therefore, in order to eradicate poverty, the poor must be given equal opportunities in the areas of production, exchange, consumption and circulation.

Second, "poverty vicious spiral theory", proposed by the American scholar Nakas in 1953, from the perspective of income and expenditure, when income can only meet basic life expenditure, the level of savings and capital is insufficient, making it difficult to make other investments. There will be a vicious circle, which can not change the state of poverty.

Third, the "circulation accumulation causality", put forward by Gunnar Muldale of Sweden. All kinds of economic factors interact with each other. Once an economic factor is not conducive to changes of the development of the whole society, it will lead to further deterioration of the entire circular system and eventually to poverty. Through the investigation of the poor countries in Asia, he proposed a solution to the relationship between education, land and rights as an effective means to eliminate poverty.

Fourth, "theories of human capital". Theodore Schulz in the United States believes that poverty is not due to the lack of material resources and financial resources, but that the development of human resources is not in place. Therefore, improving people's own ability and increasing human capital investment are the fundamental ways to solve poverty.

In general, foreign studies have laid a solid theoretical foundation for the development of poverty alleviation undertakings. And the following aspects are outstanding: the rights, qualifications and capabilities of poor households; the evaluation method of the poor households; the vulnerability and dynamics of poverty.

\section{Poverty Alleviation Relocation}

The studies on "Relocation and Relief" are mainly embodied in "Ecological Migration" and "Environmental Migration". There is no direct use of the concept of "Poverty alleviation relocation". The research is mainly focused on the causes of migration. In the book "The Relationship between Population, Environment and Poverty", Richard Leete put forward that bad environment is not suitable for existence, which will lead to immigration in the area. Scholar Souder proposed the stage theory of immigrants: gathering migration, relocation, transformation, economic development and other stages. For different reasons, immigrants need to take different methods. Scholar Engels proposed that the economic recession is the main reason of the migration in Manchester, which is the leading role of "pulling force". However, Redford argues that the reason for immigrants is non economic factors, mainly "push", that is, the lack of land resources and the enclosure movement at that time, so that people who can not make use of land to earn their living can be transferred out.

In addition, foreign research on poverty alleviation relocation of immigrants is also earlier than China, some scholars have studied the relocated migrants in Thailand, such as TianXiujuan and Chaoyang explored the poverty alleviation model which is suitable for the development of the farmers in the northern mountain areas of Thailand.Huang Haizhen proposed using the government 
forces to pay attention to the follow-up economic development and technical training of resettlement immigrants. Some scholars studied poverty alleviation relocation in China, For example, Morris-Jung studied the case of population migration due to national parks. Dickinson and Webber mainly explored the current situation of immigrant relocation in China. By analyzing the ecological migration in the plateau area of Inner Mongolia, the author put forward the idea that the development of the immigrants should be balanced with the ecological development. It is also worth mentioning that many foreign scholars study on the immigration problems caused by the Three Gorges water conservancy project in China.

\section{Domestic Research Progress}

\section{Poverty Alleviation}

Poverty alleviation, as the name implies, is to help the poor and poverty-stricken areas. The research on poverty in China started late, but it is rich in practical experience, especially in the way and methods of poverty alleviation. Therefore, the research results have some representative and practical significance. The main focus is on the following three aspects:

First, research on the model of poverty alleviation. WangSangui, a domestic scholar, started research on poverty alleviation mode earliest and summed up three kinds of poverty alleviation mode in 1994: relying on resources, accumulating assets and technology-driven; In 2012, he also pointed out: In the new period, we should pay attention to the special types of poverty-stricken areas, we should reduce poverty in special types of poverty-stricken areas by increasing the redistribution of benefits, promoting the development of regional development and improving the effectiveness of poverty alleviation management[6].In recent years, there are many studies on the model of poverty alleviation and development: ZhaoRong et al. (2014) summarized six representative models of poverty alleviation in forestry[7].Liu Yuxiang (2015) analyzed the dynamic mechanism of farmers' cooperative poverty alleviation mode and the application of management aesthetics in poverty alleviation. On this basis, a farmer cooperative poverty alleviation model in less developed areas with government initiative and social linkage was built[8].Li Xiaoyi (2017) put forward the innovative financial poverty alleviation model on the basis of field investigation to Wangdu County of Hebei province[9].

Second, precise poverty alleviation. In November 2013, Xi Jinping visited Xiangxi in Hunan, he first proposed the concept of "recise poverty alleviation" and then put forward a series of guiding principles. At present, the research on precision poverty alleviation mainly focuses on the following aspects:(1)Research on Precise Poverty Alleviation Policy.ZhengRuiqiang and Wang Ying (2016) analyzed the key problems in the process of precision poverty alleviation through the exploration of the policy of precision poverty alleviation, and put forward the trend of future policy[10].Wang Jieyong et al. (2016) elaborated the necessity and importance of implementing the precision poverty alleviation policy, and put forward the innovation path of precision poverty alleviation policy on the basis of combing the evolution process and trend of China's poverty governance policy[11].(2)Research on the way of precision poverty alleviation. According to the regional model of precise poverty alleviation, Li Yu-rui et al. (2016) thought it is necessary to further improve the regional poverty alleviation policy system, industrial policy system and land policy system, and strived to establish and improve the transmission mechanism for boosting the poverty-stricken households' poverty alleviation through regional development[12].Zhang Yuxue (2016) believed that large data technology support has a significant impact on the performance of the precision poverty alleviation process. The construction of big data poverty alleviation platform was a new model of precise poverty alleviation practice. And put forward the practical innovation path of accurate poverty alleviation in the background of large data, such as the transformation of the concept of precision poverty alleviation and the direction of accurate poverty alleviation and development[13].

\section{Poverty Alleviation Relocation}

The relocation of poverty alleviation is one of the ways of poverty alleviation and development. 
Especially after the precise poverty alleviation was put forward, it has attracted the attention of many scholars as one of the major measures of precision poverty alleviation. WangHongyu (2016) found that the distance of relocation has a significant impact on the effectiveness, voluntariness, satisfaction and adaptability of poverty alleviation and put forward corresponding suggestions through the investigation of Dingbian County in Shaanxi Province[14].Pan Shangrong et al (2016), from the perspective of satisfaction with poverty alleviation and relocation of immigrants, studied the financial support for the relocation of poverty alleviation in Qiannan Prefecture through the ACSI model[15].HouMaozhang et al. (2016) summarized the 11 models of follow-up industry development in poverty alleviation and relocation in Hunan based on the investigation of the national poverty-stricken counties in Shimen, Yuanling and Sangzhi in Hunan Province and put forward the countermeasures and suggestions on how to choose suitable industry and industrial development mode to promote the follow-up industry development according to the conditions of resettlement[16].Wu Jinqiao et al. (2015) evaluated the status of eco-immigrants in southern Shaanxi to understand the satisfaction of immigrants[17].According to the characteristics of poverty alleviation and relocation project in Gansu Province, Wang Tao (2015) adopted the method of systematic evaluation to set up the post evaluation index system for the relocation project of the poverty alleviation project. It carried out the evaluation and analysis from four aspects: economy, society, environment and characteristics, and provided a basic index framework for carrying out the post evaluation of the relocation project[18].

The problem of poverty in all countries of the world needs to be solved, although the economic development and social cultural environment are different, but with the research of population migration, it is found that the experience of helping the poor can learn from each other. At the same time, with the development of era, the focus of scholars' study is constantly changing. From researching on policy and reason to the research of people-oriented, from focusing on the number and speed of poverty alleviation to quality. At the present time, the research from the perspective of poverty alleviation and relocation is still scarce, and it is a new perspective for studying poverty alleviation and development.

\section{Empirical Analysis}

Because Henan is a large province of population and a big agricultural province in China, as of January 2017, there were 31 state-level poverty-stricken counties in Henan Province, of which Luoyang has 5, ranking first in the province. Therefore, this paper selected Luoyang City, Henan Province as the research object.

\section{Poverty Alleviation Relocation Data Statistics during the Precise Poverty Alleviation Period}

Since entering the new era of poverty alleviation, Luoyang has implemented a series of decisions and arrangements for poverty alleviation and development by the central government and the provincial government conscientiously, and put the poverty alleviation and development into the overall situation of economic and social development, improved the mechanism, reformed and innovated, and intensified the work continuously. It has steadily lifted the poverty of the 310 thousand rural poor out of poverty. However, due to the influence of special geographical environment, industrial structure and development mode, the contradiction between urban and rural dual structure in Luoyang still remains prominent. Up to now, there are 5 state-level poverty-stricken counties, 1 poverty-stricken county, 669 poor villages and 316,700 poor people.

In 2016, the poverty alleviation and relocation in Luoyang City involved 8 counties (cities), 61 townships and 264 administrative villages. In 2016, Luoyang planned to build 91 relocation settlements and relocate 5401 households with 20,615 people. The sources of funds for construction include the central special fund of 7,000 yuan per capita, provincial and municipal supporting funds of 10,000 yuan, local government bonds per capita of 14,000 yuan, infrastructure construction special fund per capita of 46,600 yuan and medium and long term loans of 31,800 yuan per capita.The planned budget of the city was 1 billion 245 million 146 thousand yuan, and the actual demand for construction was 1 billion 61 million 822 thousand and 200 yuan. By the end of 
February 6, 2016, the funds in place were 835 million 754 thousand yuan, and the rate of funds being in place was 78.8\%.As of the end of November, all resettlement sites have been started, all counties (cities) on poverty alleviation relocation of the implementation plan have complete the review and approval.81 resettlement sites have been completed and 10 resettlement sites are being built, the construction of the project has completed $96 \%$ of the total. All the projects in Yiyang, Yichuan, Mengjin, Ruyang, Luanchuan and Yanshi have been completed. 13 settlements are accelerating the construction in Songxian and Xin'an County.

As of May 2,2017, Luoyang City relocated to settle 100 settlements, 6600 households, 24095 people, the central and provincial special construction funds were 132,069,000 yuan. The poverty alleviation relocation work in Luoyang City has been advancing continuously throughout the years. The total number of relocated settlements, relocated households, relocated people and construction funds has been on an upward trend as a whole, which has increased considerably in recent years. The details are shown in Fig.1-Fig.3.

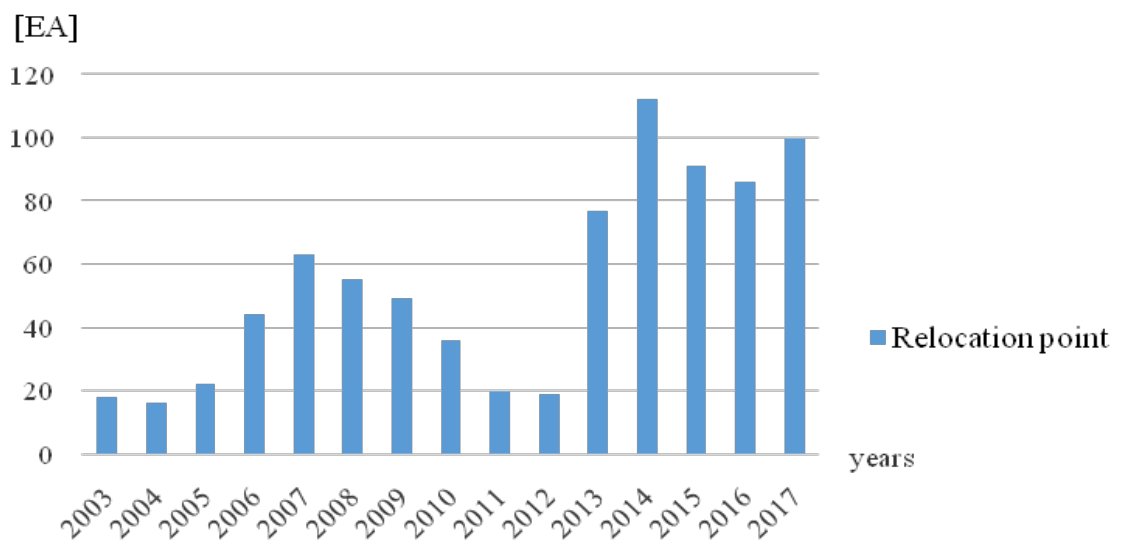

Fig. 1 The number of relocating points for poverty alleviation in Luoyang

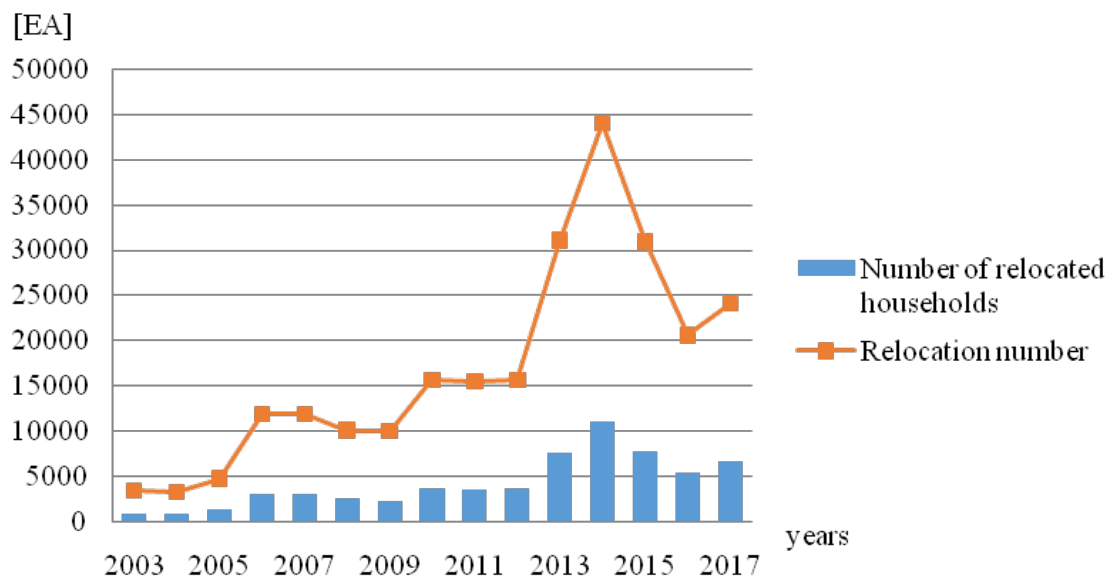

Fig.2 The number of household and people of poverty alleviation and relocation in Luoyang 


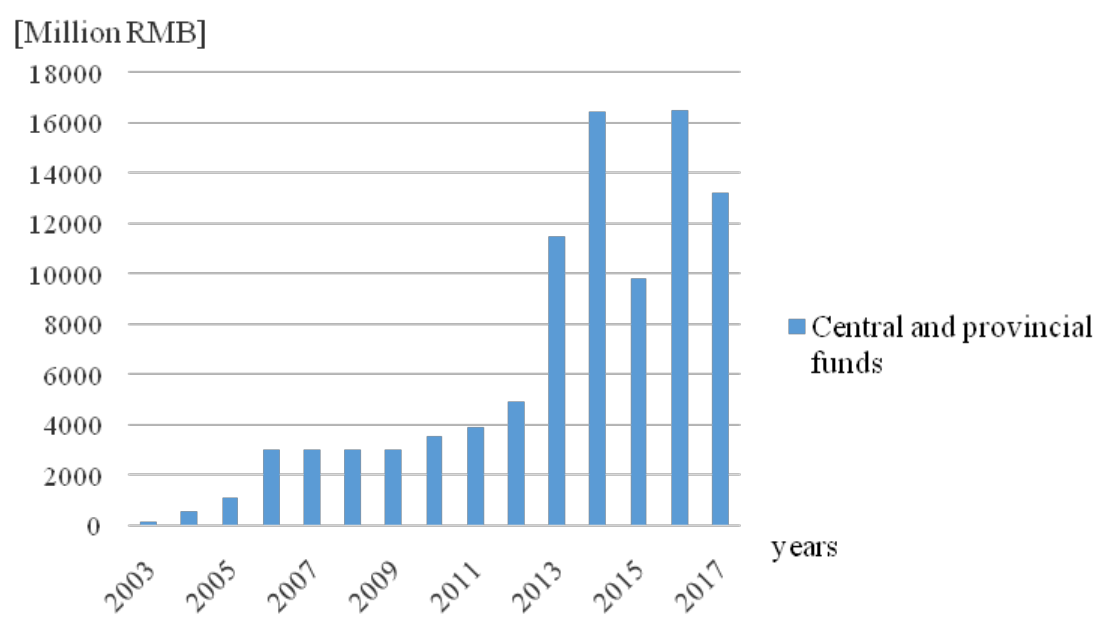

Fig. 3Central and provincial funds for poverty alleviation and relocation in Luoyang, Henan Province

Since the implementation of poverty alleviation, Luoyang has completed a total of 808 relocation points for the relocation of poverty alleviation, 62543 households relocated, 252756 people, and a total investment of 5,327,474,600 yuan. Overall, the effectiveness of poverty alleviation and relocation work in Luoyang City increased gradually from 2003 to 2014, the number of relocated households and population has been increasing in a straight line, and the best result has been achieved in 2014, which is related closely to the transformation of national and local policies and people's ideology. General Secretary Xi Jinping in 2013 first proposed the concept of precise poverty, in December of the same year, the State Council Poverty Alleviation Office Director Liu Yongfu proposed "to promote the establishment of a precise poverty alleviation mechanism and establish a national anti-poverty information system. On the basis of ascertaining the base, help measures should be formulated on a village-by-village basis so as to support the real poverty and truly carry out the poverty alleviation.”Luoyang began to implement the national policy, and began to implement the poverty alleviation in 2014.From Figure 4-1, 4-2 shows that during the period from 2014 to 2016, the state and the government invested a lot of money (Figure 3-3), but the relocation of the number of households and the number of people did not work well, mainly due to the poverty alleviation and relocation of China has entered a crucial stage. The remaining poverty-stricken population has deep poverty, the cost of poverty reduction is high, and poverty alleviation and relocation are difficult. Meanwhile, poverty alleviation relocation work pays more attention to quality rather than just quantity. The cost of reducing poverty is high, and it is very difficult to relocate people for poverty alleviation. At the same time, poverty alleviation and relocation work pays more attention to quality rather than mere quantity. Under the guidance of precise poverty alleviation, we can really help the poor and really get out of poverty. It is gratifying that by May 2017, both resettlement sites for poverty alleviation and relocation, as well as the number of relocated households, the number of people and the capital investment have shown a good momentum of development, which is expected to achieve a new breakthrough in poverty alleviation and relocation.

\section{Analysis of the Problem of Poverty Alleviation}

In the process of on-the-spot investigation and in-depth interviews with immigrants, we found that the following problems existed in poverty alleviation and relocation in Luoyang:

(1) Each person has 25 square meters of resettlement housing area can not meet the actual needs of some people. The state stipulates strictly that the area of resettlement houses can not exceed the standard. However, in the actual investigation, poor families with less than three people, especially those who have children over the age of 18, have 50 or 75 square meters can not meet the actual housing needs. The main reason is that children are facing marriages and having children. In 
the foreseeable 3-5 years, the family population will increase inevitably, and the room will not be enough to live in. In the central village, there is still room for expansion. There will be no expansion of the multi-storey resettlement housing. The masses will buy larger housing in the future, which will increase the burden. For example, a family of three in Sanhe Village, Huangzhuang Township, Mengjin County, the respondent is 54 years old, his son is 27 years old, unmarried, and his father is 83 years old. In accordance with the policy, he can only enjoy 75 square meters of two rooms and one hall, but the son will marry immediately, and the housing is unable to meet the actual housing needs obviously.

In addition, many poor mountainous areas are rich in tourism resources. The relocated masses hope to engage in the tourism service industry. And build the resettlement housing into the form of farmhouse hotels directly, which not only improves living conditions but also provides stable sources of income. But due to the provision of no more than 25 square meters for each person, it can only meet the basic housing needs of the family, and it is impossible to develop the demand of agritainment at all. If the method of reserving space for expansion is adopted, the first is to delay the pace of the people's getting out of poverty and the second is to increase the cost of the masses in the future. For example, Shuimo Village is surrounded by Baiyun Mountain, a 5A state-level scenic spot, Muzhaling,a 4A scenic spot, and Wolong Valley, a 3A scenic spot. Poor people see the masses around the house through the hotel to get rid of poverty, the average annual income of more than 50,000 yuan per household, and some reached 300,000 yuan, so they are eager to move into the farm industry after the relocation. The local village committee plans to rely on the relocation of poverty alleviation and poverty alleviation of small interest-subsidy loans, through part of the government subsidies, part of the bank loans, part of the masses to help build the farmhouse hotel, to a certain extent, which will affect the relocated people's pace of getting out of poverty.

(2) To a certain extent, the transfer of homestead has influenced the enthusiasm of the impoverished people to move. In the course of the relocation, we found that some of the poor people agreed to relocate at the beginning of the year, but when they were handed over to the homestead, they did not want to relocate. The main reasons are as follows: First, most of the poor people are conservative and the ideas of poor families are ingrained. Second, the original economic forest and farmland owned by the masses still need to be planted. If the masses turn over the homesteads, then they will have no place to live when they went back in the busy season. Third, each person who have no kith and kin and can't sport themselves can only subsidize 25 square meters resettlement housing, which has a large gap between the original homestead and housing area, the masses think it is not worthwhile. For example, there is a Li family, two couples and three children. Now they are living in the three old houses left over from the 1990s. According to the policy, they can get subsidized 125-square-meter resettlement houses. However, but when the government issued that subsidies need to sign up the agreement on the homestead, the family disagreed with the relocation strongly. A family of three surnamed Zheng, he and his brother are bachelors, the mother nearly 80 years old; there are 3 old houses with civilized structures in their home, which are not dangerous. However, they are leaking rain and are 4 kilometers away from the main road, the road is a cobblestone trail, water needs people to pick up. When the poverty alleviation cadres mobilized the family to move, the family heard that they only had 25 square meters per capita,and they must pay the homestead, they are not willing to move definitely.According to the survey and statistics of poverty alleviation cadres, among the people who applied for relocation in some areas, the number of poor households with 1-2 population basically did not have.

(3) Non-poor households have very low enthusiasm for simultaneous relocation.In accordance with national policies, whole villages under 20 households were encouraged to relocate.Non-poor households only enjoyed infrastructure and public service facilities and purchased houses at their own cost. Therefore, the enthusiasm of non-poor households is very low.According to the statistics of Song County in early 2016, the non-poor households in the county who have the willingness of simultaneous relocation are 1625 households with 6,500 people.Many people are not willing to relocate in the actual implementation process, only 780 households and 3000 people were 
relocated.Main reason:First, non-poor households can not enjoy state policies and have large psychological gaps. They all live in one village.No one can be much poorer than they are, nor can they get much richer.Poor households are moving for free. Non-poor households need to pay for their own money,which is difficult for the masses to accept.Second, the lack of purchase funds, according to the statistical data of Songxian, in 2016 the township resettlement house prices after the financial review every square meter price between 1200-1300 yuan, due to planning and design, construction tax, building standards are strict and other factors, the price of resettlement housing is even higher than the price of local market small property,non poor households need to prepare 12 130 thousand yuan to buy the house, which they can notafford. Thirdly, it is very difficult for villagers to reclaim homestead land. It is very difficult for the masses to benefit from the reclamation of homestead land, because all the relocated people live in the mountainous areas and the natural protected forest areas. The mass homestead is originally shown in the green space in the land and resources system, even if reclamation, which is difficult to get the identification of the Ministry of land. In addition, most of the villagers in the deep mountainous areas have poor site conditions andthey are very scattered, which do not have reclamation value at all.

(4)Industry support and education training can not be well combined. On the one hand, all kinds of poverty alleviation industries established mainly combine local resources such as tourism service industry. but because the basic quality of immigration is not high and they lack the appropriate knowledge and skills, which will cause adverse effects in the process of service and affect the sustainable development of the industry. On the other hand, the number of education and training is relatively small, and pertinence and timeliness are relatively weak, which made immigrant workers feel hard to do when they are engaged in the work and affect the efficiency and operation of the industry. In the long run, this will form a vicious circle.

\section{Countermeasures and Suggestions}

\section{Eliminate Poverty Conscientiously}

The realization of common prosperity is the theoretical source of "precision poverty alleviation", so precise poverty alleviation must establish the concept of common prosperity firstly. In recent years, China's economic strength, cultural strength, international influence and so on have been gradually strengthened. To achieve common prosperity is just around the corner, but the most overlooked issue is the ecological environment in the rapid development, which is affected directly in the process of poverty alleviation and relocation. Therefore, in the face of the increasingly fragile environment and resources system in the process of urbanization, wemust establish the concept of green and low-carbon development firmly, build a production and consumption pattern of resource-saving and environmentally friendly, promote the construction of an ecological civilization of the migratory and emigrant areas comprehensively and promotes the sustainable development of urban resources and the environment. On the one hand, we should improve the urban and rural environmental protection planning and policies, strengthen the greening, environmental protection and other infrastructure construction in the resettlement area, and reduce the pollution of agriculture and industry through centralized governance. At the same time, we should pay more attention to upgrading the industrial chain structure and reduce the cost of environmental governance. On the other hand, according to the characteristics of different poverty alleviation immigrant areas, we should establish precise ecological compensation mechanism suitable for the area,and guide the beneficiary to compensate the damaged interests through planning, legislation, market and other means. We should establish a guiding environmental policy system, encourage the government to transform from the traditional regulatory environmental policy to the guiding environmental policy,and guide the immigrants to takethe action that is beneficial to the development of the environmentthrough market economy.

\section{Improving the Organization Mechanism of Precision Poverty Alleviation}

A good organizational mechanism is the guarantee of precision poverty alleviation. Therefore,the 
organizational mechanism of precision poverty alleviation should be perfected so that it can exert its power accurately.First, set up a leading group, clear the subject of the project legal personand determine the leading force for accurate poverty alleviation and relocation work;Second, set up a county-level financing platform to undertake national and provincial special investment and loans so that each sum of money can be used for poverty alleviation and relocation accurately;and introducing targeted measures to promote poverty alleviation and relocation. For example, the government can establish the annual plan, project meetings, work reporting system, and ensure that the relocation work can be carried out in accordance with the rules and regulations and carry out relocation and poverty alleviation work to the full;Third, implement the responsibility system of leading cadres in poverty alleviationstrictly, establish and improve a mechanism to promote poverty alleviation and relocation,implement city-level general leaders and counties in charge, and township-level units implement the program one by one and mobilize the enthusiasm of each department, each village, each staff,so as to do a good job in all aspects of fund-raising, disbursement, project planning, site selection and construction and other relocation work.

\section{Strengthening the Propaganda of the Policy of Precision Poverty Alleviation}

In order to implement the concept of "moving a batch of people out of poverty," put forward by General Secretary Xi Jinping, the state has increased its support for the relocation of poverty alleviation and put forward many new policy bases, all of which require the relevant departments to study earnestly,keep poverty alleviation and relocation thought in mind, ensuring precise poverty alleviation and relocation policies fall to the field.First, preach policies so that people have a thorough understanding of the concept of precise poverty alleviation.According to the outline, we should preach the policy of poverty alleviation and relocation to the grass-roots level, and use all kinds of meeting opportunities to interpret the relocation policies,answer questions and enhance the grassroots' understanding of the policies.Second, the relocation site will be used to observe and learn from each other and exchange experience and experiences in poverty alleviation and relocation projects so as to play an exemplary role. At the same time, relevant documents are published in brochures, let all the personnel involved in the poverty alleviation and relocation activities be given a handbook so that everyone can grasp the national policy promptly and accurately.Third, all localities are required tostrengthen the propaganda of policies through the TV stations, broadcasting, production and publicity boards,and explain the resettlement methods, building area, subsidy standards, self-financing and demolition of old houses to the masses so as to obtain the masses' understandingand support.

\section{Plan Resettlement Sites and Resettlement Modes Scientifically}

The relocation sites are planned in accordance with the relocation scale, construction land and the principle of facilitating the masses in various regions.First, it is clearly stipulated that the planning of centralized resettlement sites should incorporate the requirements of new-type urbanization.The resettlement sites should be set uprelied on the center of town, industrial areas, tourist attractions surrounding and convenient transportation,according to the actual needs of the relocation of the masses,building the "three house mode": resettlement room,security housing and relocation housing.Second, it is required to make sure that the relocation and resettlement sites are to be "four-package" and "three-synchronized", that is, "supporting the construction of infrastructures, public service facilities, convenient service facilities, industries and income-increasing projects" at the relocation point.In specific management, we must earnestly "synchronize the establishment of a new management service organization, synchronize land transfer and land consolidation, and do a good job in education and training of villagerssimultaneously."Third, we should respect the wishes of the masses fully,combined with thecentralized resettlement and scattered resettlement.For the repurchase of vacant houses, self-construction by the masses or the investment arrangement by friends and relatives, the same policy should be implemented with the ultimate goal of helping the people to get out of poverty. 


\section{Implement the Relocation of the People to Get Out of Poverty}

First, implement the "Policy-Huimin Project". In order to enable the relocated people to "move out, remain stable andget rich",all localities explore the implementation of the policy of benefiting the people on land for relocation, property protection, financial support, employment and resettlement actively, give priority to providing microcredit and employment opportunities to the relocated people .Second, implement the batch classification of "resettlement employment project".For the relocation of households to provide rich project,provide poverty alleviation loans and support funds; classify employment support according to the actual conditions of the resettles, provide public welfare positions for those who are fit and have employment intentions;those who have the skills to work can be arranged to townships, village private enterprises and the surrounding supermarkets, restaurants for employment.In addition, we can introduce labor-intensive enterprises such as electronic products processing and garment processing in the relocation community. Third,implement the“vocational skills training” project.Carry out cultivation, breeding and vocational skills training for the relocated households, implement the export of labor servicesvigorously, establish the labor export platform actively, provide employment service information, learn from the experience of work and learn technology abroad so as to get rid of poverty and prosperity;at the same time,encourage immigrants to return home to start their own businesses, helping poor people become rich,achieve mutually beneficial win-win situation.Fourth, implement the "asset revitalization project."And to re-develop or utilize the assets through rehabilitation, rent-back and circulation, vigorously develop tourism agriculture and ecotourism, and relocate the return of assets the masses. Re-farming, rent back, circulation and other forms of assets for secondary development or ecological restoration develop the tourism agriculture and eco-tourism vigorously,andthe income of assets is used to feed back the relocated people.

\section{Acknowledgements}

This research was financially supported by the Henan Province Philosophy and Social Sciences Planning Project "Research on Social Inclusion of Relocating Poverty Alleviation and Resettlement in Henan Province from the Perspective of Accurate Poverty Alleviation” (No.2016BJJ016); Luoyang Social Science Planning Office Project "Research on Satisfaction of Resettlement Poverty Alleviation and Resettlement in Luoyang City from the Perspective of Accurate Poverty Alleviation” (No.2017B018).

\section{References}

[1]Xi Jinping.Win the battle and build a well-off society in an all-round way and win thegr eat victory of socialism with Chinese characteristics in the new era -- report on the ninetee nth National Congress of the Communist Party of China [RB/OL]. Xinhua,www.gov.cn/zhua nti/2017-10/27/content_5234876.htm.(In Chinese)

[2]Deng Weijie. The difficulties, countermeasures and paths of precision poverty alleviation [J].Journal of Rural Economics, 2014 (6): 78-81.(In Chinese)

[3]Huang Chengwei, Qin Zhimin. The evolution of rural poverty governance system and poverty alleviation in China precision poverty alleviation, [J] .Development Research, 2015 (2): 56-59.

[4]”Thirteen-Five”Poverty Alleviation Program [EB / OL] . http: //www.gov.cn/zhengce/content/2016-12-02.(In Chinese)

[5]Tang Ren Wu. Xi Jinping's idea of precision poverty alleviation [J]. People's Forum, 2015, (30): 28-30.(In Chinese)

[6]Wang Sangui, KuangYuanpei.Studies on the convergence of poverty areas and poverty alleviation and development in the new period [J].Huxiang Forum, 2012 (2), 80-84.(In Chinese) 
[7]ZHAO Rong, YANG Xu-dong, CHEN Shao-chi et al. Study on poverty alleviation model of forestry [J]. Forestry Economics, 2014,36 (08): 98-102.(In Chinese)

[8] Liu Yuxiang. Research on farmers' cooperation and poverty alleviation mode in underdeveloped areas [J] .Agricultural Economy, 2015,36 (07): 37-45 + 110-111.(In Chinese)

[9] Li Xiaoyi. Research on the innovation of financial poverty alleviation model in Wangdu County, Hebeiprovince[D]. Hebei Normal University,2017.(In Chinese)

[10] ZhengRuiqiang, Wang Ying. A preliminary study on the policy of precision poverty alleviation [J]. Financial Research, 2016 (02): 17-24.(In Chinese)

[11] Wang Jieyong, Chen Yufu, Yan Maochao. Research on China's policy on precision poverty alleviation and its innovation path [J]. China Academy of Sciences, 2016,31 (03): 289-295.(In Chinese)

[12]Li Yu-rui, Cao Zhi, Zheng Xiao-yu, et al.A regional model of implementing precise poverty alleviation in China and its sustainable approaches [J]. Chinese Academy of Sciences, 2016,31 (03): 279-288.(In Chinese)

[13]Mo Guanghui, Zhang Yu Xue. The innovation path of precision poverty alleviation mode under the background of big data -- a series of studies on the precision poverty alleviation performance improvement mechanism ten [J]. Theory and Reform, 2017 (01): 119-124.(In Chinese)

[14] Wang Hongyu.Research on poverty alleviation immigration model based on different relocation distances - Taking Dingbiancounty in Shaanxi province as an example [D]. Shanxi Normal University, 2016.(In Chinese)

[15] Pan Shangrong.A Study on the financial support for relocating poverty alleviation and relief based on the satisfaction of poor households - acase study of Qiannanprefecture [J] .Journal of Regional Finance, 2016 (10): 58-62.(In Chinese)

[16]HouMaozhang, Zhou Jing.Study on the follow-up industry development of poverty relief in Hunan province [J]. Economic Geography, 2017,37 (08): 176-181.(In Chinese)

[17] Wu Jinqiao, Zhu Jianhong, Tao Zhiyong et al. The evaluation and countermeasures of ecological migration in southern Shaanxi province--a questionnaire survey based on the perspective of farmers [J]. Anhui Agricultural Sciences, 2015, (31): 333-334361.(In Chinese)

[18] Wang Tao. Research on post-poverty relief project in Gansu province [D]. Lanzhou Jiaotong University, 2015.(In Chinese) 